\section{Justyna Tabaszewska \\ Institute of Literary Research of the Polish Academy \\ of Sciences}

\title{
The Price of Participation. Short-Range Cultures and World Literature
}

\begin{abstract}
This paper discusses the problem of how short-range literatures function within the system of world literature. The aim of the text is to show that too optimistic assumptions about the dynamics of world literature circulation and failure to recognise strong competition within this system may translate into further marginalisation of shortrange literatures and/or too much globalisation of literature.
\end{abstract}

Keywords: world literature, short-range culture, collective memory, multidirectional memory, dialogic memory.

\section{Preliminary remarks}

The starting point for this paper is the experience of a clash — both in my own research practice and in contemporary humanities - of two separate or even opposing tendencies. I deliberately write here about tendencies, not currents, movements, or turns, because the phenomena I wish to discuss here are present (although not always in the same way or in the same proportions) in practically every contemporary direction of development in the humanities. The first is expressed in the desire to close the research field, to isolate increasingly detailed, well-defined and comprehensive research perspectives, to set clear research objectives and even clearer reasons why specific research is to be 
important to the humanities. It can be described as dominant, and the reasons for its preponderance are not only scientific: it is much easier to write grant projects and apply for their financing when it is possible to clearly parcel out the research field, indicate its novelty and innovativeness, and define precise, sometimes even disturbingly precise, reasons, objectives, and effects of the research to be conducted.

The second trend aims not at dividing and creating new research perspectives, but at seeking links between what is already known and opening well-defined research directions by asking previously unanswered and sometimes even unthought questions, by pointing out gaps in their functioning and by looking for possible - not always obvious - relations between specific fields of research. I would like to emphasise straight away that these two tendencies do not have much in common with the division into disciplinary, interdisciplinary, or transdisciplinary research. ${ }^{1}$ The transdisciplinary research type in which the first, closing trend is observable, as well as research within a single discipline, which is clearly open-ended, are both possible (and in grant applications it works perfectly).

The awareness of the existence of these tendencies, differently named or described, but indicating the same phenomenon and related research intuition, is becoming increasingly common. ${ }^{2}$ Nevertheless, most often little follows these observations (not because they are unconvincing or badly argued), just as little follows from the growing objection to the grant system of funding the academy (or at least the grant system as the dominant model of financing research). Again, I have to make it clear that I do not think that one of these tendencies is essentially 'good' and the other is 'bad'. Nevertheless, I believe that there is now a sharp imbalance between them, with a strong dominance of the first trend. And this I consider unfavourable to academia. A particularly worrying phenomenon can even be observed in the use of these trends in a conjugated way: first, a given field or direction is supposedly opened to track the possible gaps or discontinuities, then it is closed to indicate-implicitly or explicitly - the methodology, phenomenon, or new direction that solves the 'half-closed' problems.

I do not intend to analyse these trends in themselves in this text, nor do I intend to write about how they may affect the development of academia.

1 See the conceptualisation of this distinction introduced by Ryszard Nycz in relation to literary studies: R. Nycz, Kulturowa natura, słaby profesjonalizm. Kilka uwag o przedmiocie poznania literackiego i statusie dyskursu literaturoznawczego, in: Kulturowa teoria literatury. Główne pojęcia i problemy, eds. M.P. Markowski, R. Nycz, Kraków 2006, pp. 29-30.

2 Cf. P. Czapliński, Sploty, "Teksty Drugie” 2017, no. 1, pp. 9-17; R. Nycz, Nowa humanistyka w Polsce: kilka bardzo subiektywnych obserwacji, koniektur, refutacji, "Teksty Drugie" 2017, no. 1, pp. 18-40. 
However, I want them to be the background for the analysis of two concepts conceived as a method of opening up a certain research field: world literature and the categories of multidirectional and dialogic memory, which are - in my opinion-in correlation with them.

\section{Negotiating the world literature system}

The concept of "world literature", which I deliberately, but so far without explanation, put in quotation marks, is one of the most important and one of the most frequently redefined categories in contemporary humanities. There are various, well-thought-through and engaging conceptualisations of this notion, created by e.g. David Damrosch, ${ }^{3}$ Pascale Casanova, ${ }^{4}$ Franco Moretti, ${ }^{5}$ orfrom more critical perspectives - by Emily Apter, or Eric Hayot. ${ }^{6}$ I am not going to question their importance or the permanence of the concept itself, but I am going to check the extent to which the category of world literature can be regarded as a theory that really opens up literary research to new contexts, and to what extent it preserves the existing state of affairs, perhaps contrary to its own intentions.

The core creators of all the aforementioned conceptualisations of world literature express the conviction that there is a specific mode of existence of world literature at all, which is to be something else than a collection of national literatures, other than simply a literary canon, and does not follow the tradition of classically understood comparative literature (although undoubtedly the relations between these concepts are not as unambiguous as it might seem at first glance). ${ }^{7}$ I am deliberately presenting here the most general conditions that shape the notion of world literature and I do not fully define the relation-

3 Cf. D. Damrosch, What Is World Literature?, Princeton, NJ, Oxford 2003; idem, How to Read World Literature, Malden, MA, Oxford 2009; Teaching World Literature, ed. D. Damrosch, New York 2009.

4 Cf. P. Casanova, The World Republic of Letters. Convergence: Inventories of the Present, transl. M.B. Debevoise, Cambridge, MA, London 2004.

5 Cf. F. Moretti, Conjectures on World Literature, "New Left Review" 2000, no. 1, pp. 54-68.

6 Cf. E. Apter, Against World Literature. On the Politics of Untranslatability, London, New York 2013; E. Hayot, On Literary Worlds, Oxford, New York 2012.

7 A.F. Kola, Między komparatystyka literacka a literatura światowa, "Teksty Drugie" 2014, no. 4, pp. 41-63. 
ship with these concepts, as different scholars understood them in different ways. What was supposed to be a distinguishing feature of world literature was also often described as a dependence on a specific mode of reading. ${ }^{8}$

I do not intend to note here any opposition to some conceptualisations of this term, nor all the more, although I often object to them, to defining world literature more often in opposition than in relation to national literatures. The very term "national literature" is sometimes undefined in these concepts or, on the contrary, treated as a phrase with a completely unambiguous, stable meaning, in which the real existence of national literature is taken for granted and its structural character is disregarded. What I would like to reflect on is the very reality of this concept and its relations with other humanist repetitive demands for the creation of cultures, literatures, traditions, or memories, across certain divisions that are difficult to ignore.

Before I specify the research problem discussed here and its relation to the doubts expressed about the openness of this discipline, it is worth quoting one of the best-known definitions of world literature (and by far the most convincing), created by David Damrosch:

World literature is an elliptical refraction of national literatures.

World literature is writing that gains in translation.

World literature is not a set canon of texts but a mode of reading:

a form of detached engagement with worlds beyond our own time and place. ${ }^{9}$

This well-known three-part definition focuses, as Damrosch points out, on the world, the text, and the reader. These three quoted points are connected by movement: "elliptical refraction" means, in fact, the ability to exist in a context other than the original one, the ability to join a circuit different from the national one, and thus the ability to transform. The process of gaining in translation means not that literature is objectively "better" in literary terms, but that with double migration, linguistic and territorial-conceptual, a text accumulates new meanings. Surely-which is less often said-some of the meanings become more difficult to trace in such a case. However, if it were possible to make a profit-and-loss balance, it would be positive for migrating literature, and this is a declared or hidden assumption of all the theories of world literature. This point also contains a reservation, directly expressed by Damrosch: texts that lose in translation cannot become part of world literature. This means that some literary texts are in fact doomed not to function outside the framework of national literature, or - which may more accurately describe the same intuition - outside a particular cultural circle. This reservation is im-

8 Cf. for example P. Czapliński, Literatura światowa i jej figury, "Teksty Drugie" 2014, no. 4, pp. 13-40, D. Kołodziejczyk, Wojna światów? Postkolonialny kontrapunkt w nowej komparatystyce, "Teksty Drugie" 2014, no. 4, pp. 64-84.

9 D. Damrosch, What is World Literature?, op.cit., p. 281. 
portant because it points to two problems. Firstly, not every text can become part of the world literature system. Secondly (and this is a practical effect to which world literature researchers are reluctant to admit), it is much easier for a text written in one of the more widely known languages to join this group. Also, but not only, because sometimes it is not necessary to translate a text in order for it to exist in world literature.

This means that the first two points of the quoted definition indicate-both directly and indirectly - the selective character of the process of incorporating a text into the body of world literature. If one were to measure the potential of each text to become part of this system, it would turn out that being written in a language widely known and easy to translate (also for reasons of availability of translators), or even one that does not require translation may be one of the deciding factors. Equally important is knowledge of the home context, i.e. local literature and culture, which facilitates the transfer of texts from dominant cultures and languages. To sum up, this means that there are cultures from which it is much easier to migrate to world literature and cultures where such transfer is difficult. In my opinion, this fact is not completely neutral for the concept of world literature, but it is most often treated as such by scholars.

The last part of this definition focuses on the reader, who is to undertake a specific task, which is not only to place the text in a new context, but also to go beyond the reference point typical of his or her own literature and culture.

This requirement was the most widely discussed part of Damrosch's theory, also in Poland, ${ }^{10}$ and one can risk the claim that it was decisive for the popularity of this theory. I do not intend to argue with its postulatory character, because it is easy to agree that if world literature is to function as world literature, then this requirement is prerequisite: the recipient's detachment from the universe of his/her own space and time, which he/she knows well, is crucial. Nonetheless, the question of whether this is possible remains open, in my opinion.

Trying to answer them, it is worth considering what "beyond our own time and place" really means. The first requirement that appears in the quoted point, the requirement of selflessness, resembles the classical Kantian definition of art. ${ }^{11}$ This was also about detachment from specific needs. Here, however, this requirement is stricter. It is not so much about disinterestedness understood as no direct profit, no expectation of pragmatic benefits, or the promise not to use art for purposes other than those set by art itself. This definition goes one step further: it demands the same disinterested interest when literature tells us nothing about ourselves, our problems, and our world. Therefore, a reader is

10 Cf. for instance P. Czapliński, Literatura światowa ..., op.cit.; A.F. Kola, op.cit.

11 According to Kant, this was the main criterion distinguishing art from crafts. Cf. I. Kant, Critique of Judgement, transl. J.C. Meredith, ed. N. Walker, Oxford 2007, pp. 133-142. 
required to be disinterestedly interested in what is foreign to him or her and is in some sense supposed to remain foreign. If it turns out that a particular literary text is included in the system of national literature, ${ }^{12}$ or is read as telling something - perhaps not directly or frankly — of our time and place, then it is not treated as a part of world literature, but as an element that broadens another national literature.

The paradox I am pointing to is not only a flaw of this type of thinking about world literature alone, nor does it refer exclusively to the conceptualisation of this notion by Damrosch. On the contrary, the vision of creating transnational communities, or at least circulations in which literature and other cultural media can function, is currently shared by scholars of different specialities. Damrosch's proposal is all the more interesting because, according to it, this community is established each time in the experience of the reader, and is not an objective, describable set of texts: "World literature is not an immeasurable body of material that must be contained in some impossible way. It is a mode of reading that can be experienced intensely with several works and as effectively as with extensive research on a large number of works." ${ }^{\prime 3}$

Reading is, therefore, not about establishing a corpus of texts belonging to world literature, nor about discovering or reconstructing the contexts of literature functioning within the system of world literature. It is about the experience of resonating texts (from different sources) that reverberate with each other and with the knowledge of the reader, about establishing new connections. Abandoning the typology and definition of Damrosch, this mode of reading could therefore be called multidirectional reading, which is supposed to send us beyond our time and place, set us in motion, and make us discover a different reality than the one that we know well.

The notion of multidirectional reading I have proposed here (which is not to be an independent research category, but a way of presenting the intuition behind Damrosch's definition) is obviously partly borrowed from another concept, designed to deal with a different problem. What I have in mind is the

12 I use the notion of national literature only in reference to the binary understanding of the relations between the world and national literatures established within the world literature. In this sense, the term is most often used to describe local literature written in a specific national language and in the case of which the local cultural context is important for understanding and interpretation. In this case, national literature does not mean nationalist or patriotic literature, etc., although it can be co-created by individual texts of such character. The adjective "national" has exactly the same meaning in relation to collective memory.

13 D. Damrosch, What Is World Literature?, op.cit., p. 299. 
concept of multidirectiona $1^{14}$ and dialogic ${ }^{15}$ memory, created in response to the construction of closed, national visions of memory and building around them inclusive memory communities. Before I move on to describing the relationship between these concepts, I would like to return to the starting point signalled at the beginning of this paper, which was the observation concerning the current existence of two separate tendencies in humanities: closing and opening. At first glance, the concept of world literature seems to be an example of the latter. It enables us to look at literary texts outside their original context, it gives individual works not even a second life, but an infinite number of new appearances, created each time by the reader, who constructs his or her own microcosm of world literature and weaves a network of references that is readable only to him-/herself.

World literature understood in this way seems to be as open as possible. It is supposed to make texts move, to enable them to be outside their own time and place, to offer the possibility of being entangled in a different reality, both literary, cultural, and social. In this respect, it does not in any way resemble the concept of a literary canon or literary tradition in their classical (often restrictive) understandings. ${ }^{16}$ And yet: it seems to be open, but is it really open? This may not necessarily be the case, as indicated by such understandings of world literature according to which it is the emanation of the closing tendency in research. According to them, world literature as a certain system can only work because we agree to further exclusions resulting from the assumed translatability (linguistic, but also cultural) of texts. To put it differently: the system of world literature does not work as Damrosch, among others, would like and multidirectional reading cannot be successful because it encounters specific obstacles. The greatest one is the fundamental untranslatability of cultures, the full impact of which on every global system is not fully realised by researchers of world literature. These objections, put forward by, among others, Emily Apter, ${ }^{17}$ were aptly discussed by Przemysław Czapliński, ${ }^{18}$ who pointed to the source of the slip in the description of the functioning of world literature. This

14 M. Rothberg, Multidirectional Memory: Remembering the Holocaust in the Age of Decolonization, Stanford, CA 2009.

15 A. Assmann, From Collective Violence to a Common Future: Four Models for Dealing with a Traumatic Past, in: Conflict, Memory Transfers and the Reshaping of Europe, eds. H. Gonçalves da Silva et al., Newcastle upon Tyne 2010, pp. 17-20.

16 I am referring to this direction in defining a tradition or canon that emphasises their durability and describes them in terms of a collection rather than a dynamic system. Interestingly, even some contemporary scholars are returning to this understanding of these concepts (the case of Harold Bloom is significant here; after the definitely opening concept of fear of influence, he formulated a very limiting concept of the canon in: H. Bloom, The Western Canon: The Books and School of the Ages, London 1995.

17 E. Apter, op.cit.

18 P. Czapliński, Literatura światowa..., op.cit., pp. 34-35. 
source is reality, not described well enough and not taken into account enough in the construction of the rather harmonious concept of the functioning of world literature.

However, if the system of world literature is to work, it must be taken into account that literary texts not only establish relations with each other, consequently building a certain system, but also compete with each other to find their place in this system and push other texts out of it. If the concept of world literature is to describe this system and participate in the construction of the "best of all possible" versions of it, its advocates need to first become fully aware of this situation. They must open this concept to a reality that is not harmonious at all.

How? To a certain extent, but only to a certain extent, concepts developed by studies on cultural and collective memory may be a hint.

\section{An inevitable conflict}

Studies on collective memory, although its tradition is much shorter than that of literary research, ${ }^{19}$ have experienced a similar opening in recent years. The first years of research on remembrance definitely belonged to national or smaller memories, but still operating within the framework of national communities' memories. The result of intense exploration of closed modes of remembrance, often built by specific memory policies, were observations on the need to build a memory framework that would be more susceptible to tears and discontinuities than, for example, national memory, and capable of interaction - other than confrontation - with different versions of memory.

The answer to this need was at least two widely known concepts of memory: the concept of dialogic memory proposed by Aleida Assmann and the concept of multidirectional memory proposed by Michael Rothberg. Both emphasised the necessity of opening the memory field in such a way that different versions of memory could coexist in it. Assmann recognised that individual collective memories, especially national memories, compete with each other: "As a rule, national memories are not dialogic but monologic. They are constructed in such a way that they are identity-enhancing and self-celebrating; their main function is generally to 'enhance and celebrate' a positive collective self image. ${ }^{20}$

19 Cf. A. Assmann, Cultural Memory and Western Civilization: Functions, Media, Archives, Cambridge 2011, p. 176; J.K. Olick, The Politics of Regret: On Collective Memory and Historical Responsibility, New York 2007.

20 A. Assmann, From Collective Violence..., op.cit., p. 17. 
According to Assmann's concept, dialogic memory would consist in transforming the memory structure in such a way that it would be possible to remember not in terms of "either-or" but "both-and". The project of dialogic memory was to lead to the transformation of two planes on which memory functions. The first one is the memory of a specific group or community, including a national memory. In this aspect, dialogicality was supposed to broaden the spectrum of roles acceptable within the national memory, which are usually limited to three: the role of the victor, the liberator, and the victim. This extension was, therefore, intended to allow people to think about their own nation also in terms of the perpetrator of violence and, for example, a witness or observer who takes a passive view on certain events.

Of course, this expansion of the memory framework can - and, in a sense, is supposed to-lead to conflict situations. Conflict, however, is in this case only one of the stages, not a natural state of memory, and can lead to permanent change. It is not about working out a compromise, understood as creating one, perhaps even nuanced, version of memory, but about allowing the coexistence of different versions of memory, sometimes contradictory, in one space.

The change within national memories could enable the creation of a new framework for European memory, which in such a case would be something more and something else than just a collection of competing, sometimes contradictory versions of national memories. Its most important feature was to be the aforementioned dialogicality, i.e. the recognition that there is no single overarching perspective from which a certain event can be remembered. This means that instead of conflict, it would be possible for different versions of memory to coexist peacefully; despite the fact that they would always clash, their interaction would be shaped not only for the sake of the past but also for the sake of the future. In this respect, dialogic memory could be a tool for integration that would make it possible to look in the past not only for divisions but also for common points, and to look at the past not in order to preserve the account of regrets and harm, but also to learn lessons for the future.

The vision presented is to some extent a postulate, and to some extent it describes the process that actually started to take place. Michael Rothberg's concept, expressed in the book Multidirectional Memory, has a similar character. It is both more idealistic and more realistic than Assmann's concept. Its point of departure is more realistic: Rothberg notes that the phenomenon of memory competition concerns not only conflicting versions of memory for a specific event, but the entire sphere of memory. To put it more vividly: it is not only that, for example, only Polish, French, German, and Russian versions of the memory of World War II compete in the European field of memory, but that competition also affects events and versions of memory that are completely unrelated to each other: the memory of World War II may lose out to the memory of World War I, which may in turn lose out to the memory of decolonisation or political transformations after the fall of communism. The exam- 
ples given are of course random and concern only the local European memory, which-like any memory - participates in global memory, co-shaped by the memory of events which have no meaning from the European perspective (or, using the language of Damrosch, they have a meaning when we decide to move beyond our own time and place).

In this specific chaos of memory, born out of the overlapping of ever wider and ever more distant memory perspectives on each other, something that Rothberg calls knots or nodes of memory can be considered as observation points. And here his concept becomes much more idealistic than Assmann's proposal. The category of memory knots allows Rothberg to put forward the thesis that certain historical events, if we look at them from different perspectives, and not only from one, assigned to the construction of a particular national memory, can function as a space of building an affect necessary to create a multidirectional memory, namely solidarity. As he points out, solidarity is understood here as an affect that "involves a feeling of implication in and accountability for histories not considered 'one's own'". ${ }^{21}$

The experience of solidarity, if it is to happen at all, must therefore result at the same time from the intellectual and emotional recognition of one's ownboth individual, social, and national - immersion in affairs and events that do not seem to us to be the most important. Therefore, it is an action contrary to the deeply traditional lines of division, which mark the boundaries of memory that is important for the creation of national identity. In order to better understand the dynamics of this process, it is worth quoting another fragment: "Such flows are among the sources of what I have called memory's 'multidirectionality', a dynamism in which multiple pasts jostle against each other [...]. Like empire, memory is simultaneously disjunctive and combinatorial: it both disassembles and reassembles." 22

The vision of a dynamic, multidirectional memory, which can be "disjunctive" and "combinatorial" not only to achieve a relatively coherent memory, but also to fulfil a very ethical postulate to take on the responsibility for stories of "others", is extremely tempting. And in my opinion, it considerably resembles Damrosch's earlier postulate, mentioned before, to move beyond one's own time and place. A praiseworthy postulate, but - in the case of each of the concepts discussed - difficult to implement if one does not take into account certain problems resulting from an attempt to separate oneself from one's own time and place, i.e. from the reality that is not very harmonious and not currently focused on building realistically communal versions of anything, either memory, literature, or politics.

21 M. Rothberg, Between Paris and Warsaw: Multidirectional Memory, Ethics, and Historical Responsibility, in: Memory and Theory in Eastern Europe, eds. U. Blacker, A. Etkind, J. Fedor, New York 2013, p. 92. Emphasis-M.R.

22 Ibidem, p. 86. 


\section{Reality and an inevitable trip}

The theories discussed here - briefly and certainly with some simplificationsare rooted in the postulates characteristic of the opening tendency. Their aim is undoubtedly to broaden the scope of the discussion and to direct it towards the problems that were previously hardly perceived. It is also clear that there is an ethical aspect to the concepts that underline the obligation to look at a particular system (be it literature or memory) from a perspective broader than just a national one. At the same time, however, it is impossible not to notice certain problems with the practical implementation of these postulates. I do not mean here only the often criticised assumptions concerning the functioning of world literature, which does not sufficiently take into account problems with translating texts and differences in translatability (i.e. the possibility of implementing the postulate of "gaining in translation" from different languages), or the excessive centralisation of this idealistic, non-centralist system, which in practice is still shaped from the point of view of the current cultural centre, but above all the relations between the presented concepts and reality, or to put it more clearly: too little interest in how the world literature system actually works - if it works - and how multidirectional or dialogic memory will work-because it rather does not work yet. While the concept of world literature can hardly cover the situation of competition between individual texts (and yet in world literature, whether we like it or not, there is also a "notorious lack of space"), the concepts of multidirectional or dialogic memory conceive an equally simplistic - too idealistic, insufficiently realistic - way to change this state of affairs, although they describe well the competitive or even conflicting starting point.

The mentioned problem with reality was reported by scholars, and more by those who hail from cultures that can be labelled as short-range ones. It is worth quoting Przemysław Czapliński's remarks here that conclude his moderately critical paper on the possible conceptualisation of the notion of world literature:

A literary scholar has to ask questions that require going beyond literature: is the world a system — uniform but unequal — or a multiplicity of systems? Can literature preserve its autonomy and equality within this system(s)? Can the transfer of literary models from the centre to the semiperiphery and to the periphery be permanently disrupted or reversed? [...] So today's study of world literature is a participation in the conflict of metaphors [...]. In this dispute it is impossible to diagnose the conditions for the autonomy of literature without hypotheses on the functioning of the world..$^{23}$

23 P. Czapliński, Literatura światowa..., op.cit., p. 39. If not stated otherwise, all the quotations were translated by Kaja Szymańska. 
It is the "hypotheses on the functioning of the world" that are the weakest element of the concepts discussed, and it is they - or more precisely the lack of them - that make the vision of how the system of world literature and memory can really be opened unconvincing, even if the critical aspect of theory is cogent. For the simplest and most difficult problems to avoid are not taken into account: nobody is ever entirely beyond their own time and place, sometimes - and only sometimes-some are interested in what is different from their perspective.

The system of world literature and the system of global memory function in a similar way. According to the postulates, they are systems of equal rights and equal access, but in practice they are based on the dominance of long-range cultures. I deliberately use the terms "culture of short and long range" here because, in my opinion, they better reflect the dynamics of the relations between cultures than the division into the centre and the periphery. Cultures that have a long reach at any given moment may of course change in time (although not quickly and not easily, given the current advantage of English over other languages, for example ${ }^{24}$ ), but they always determine the scope of what can be considered interesting at all beyond one's own time and place. The same is true of the memory system: even if it is indeed possible to remember certain events in a dialogic or multidirectional manner, it almost always happens not on the principle described by Assmann as "both-and", but rather according to the paradigm "in general it is so, and besides". Thus far marginalised memory gains its place. However, not as an equal partner, but rather on an exceptional basis, as a point of view - it should indeed be taken into account, but this does not make it equally important.

Why is this inequality so significant in my opinion? Why do I attach so much consequence to the indication that important concepts, which do a lot of good in humanities, are unrealistic and assume a glorious but practically unattainable starting point (being beyond one's own time and place), and secondly, they consider possible a situation of balance in a system which - as it is recognised in each of these theories at some stage - is fed with conflict and struggle for a dominant place rather than peaceful coexistence? Because leaving these problems unsaid changes these - to all intents and purposesopen theories into concepts that preserve the current state of affairs, in which the dominance of long-range cultures is not only absolute, but - which in my opinion is the worst - can become transparent, completely imperceptible, as if it was not the result of long-term status quo, but a natural consequence of a system conceived as dialogic, open, and multidirectional.

24 This advantage cannot be violated by other languages and the growing number of their users, since the knowledge of English is still a prerequisite for participation in world culture. 
This "closing" of these theories is not intentional and declarative, as was the case with some other definitions that function in a related field (such as the restrictive definition of a canon or tradition ${ }^{25}$ ), but it does not become less real. When we forget about the current state of literature and memory, which is a state of clear dominance of specific options, be it national literature or collective memories, we cease to notice that even the implementation of the postulate of being "beyond one's own time and place" will never be disinterested, because a long-range culture will only allow for things that are noteworthy from its perspective. This is why short-range cultures will continue to be subordinate, not because of the argument of "superiority" or "betterness" of a given system, which is recurring in other discourses, but for purely pragmatic reasons: what is more catchy because it reaches a larger number of recipients, will be in the centre, which will be joined by what is interesting in other cultures in terms of translatability of cultures. These interesting elements will, however, play the role of a context rather than an equal partner.

Of course, such an exchange may look different between short-range cultures. Or rather, it could, but it will not. It will not be, because the way to exist in the global network of references is not to open one's own culture, literature, or memory to other local cultures of short range, but to always be in relation to the global circulation, to strive to become the most possibly translatable, to "gain in translation".

Thus have we come to the core of the other problem most significant in this paper. The postulate of translatability is not only an innocent description of reality that tells us what actually enables texts to join the circulation (or circulations) of world literature. It is the condition that can determine (and does determine) the development of short-range cultures, ever more (and not less) turned towards the global market of memory or literature. Short-range cultures are looking for a niche on this market, a place to settle in, and try (more or less successfully) to negotiate their own place.

This niche searching process is particularly visible for memory systems. Dialogic memory, or at least what can be considered an attempt at its implementation, is further shaped within the framework of conflict and displacing certain versions of memory by other ones. In addition, now the position of memories that has dominated so far is even better as they cannot be accused of blocking other versions of memory. The conflict has moved from the main field to the niches. Now, the struggle for existence within the main discourse, for being mentioned as a counterpoint within a single, compact memory framework, is taking place between local, excluded memories. The dynamics

25 Of course, not all the conceptualisations of these concepts were closing. Nonetheless, their most popular use assumed thinking of texts as a kind of relatively stable, difficult to change formula, much less susceptible to transformation than a dynamic and changeable concept of world literature. 
of this process consist in creating a single, relatively consistent narrative about a given event and allowing - by way of exceptions - specific, also compact, versions of events, ensuring they will not be equally important for shaping the memory framework. What kind of versions would that be? The ones that are translatable in relation to the currently dominant memory framework; the ones that fit within its framework. This does not necessarily mean that they must be fully compatible with this framework. However, they are always in relation to it. Even if they do not support it, they may close gaps in it; if they do not close the gaps, they constitute the opposite point of view, but still: they are conceivable within this structure, translatable into its language and, from its perspective, they are currently relevant.

Translatability - and more so "gaining in translation"-is, therefore, a prerequisite for any worldwide circulation of culture, literature, or memory. Every short-range culture, aware of its limitations, is also aware of the need to strive for participation in the global circulation. And it has its price, completely different for long-range and short-range cultures. And this price is often forgotten by researchers of world literature, among others, as shown by examples from contemporary research on memory.

\section{Price}

If they want to participate in the system of world literature, short-range cultures must forgo certain things and take others mortally seriously. What can they give up? Translations into local languages. What they cannot give up? Translations into congress languages. Regardless of the fact that perhaps some texts could more successfully adapt to the context of other short-range cultures, a related language (in the case of Polish - other Slavonic languages) would give them a much better chance to "gain in translation". However, this price is not the highest. One can argue that every literary text loses in translation in terms of precision and idiomatic beauty, but gains from new references, senses that are born in contact with a different system than the native one. What happens to the text from a long-range culture when it is incorporated into the system of world literature? Most often it enters together with at least the basic native context, readable to the audience outside this culture. What happens to the text of short-range culture in exactly the same situation? It begins to function without context or in a context that has been prepared by researchers, translators, and interpreters according to what they consider potentially interesting for the reader from a different culture. I would like to stress that I am not criticising either the reading of texts outside their original context, or even less the attempts to distil some kind of original context as a possible background for interpretation. Nevertheless, the world literature system is 
most often seen as functioning more or less in the same way for every text. And this is not how it works. In the case of texts from dominant cultures, a large majority of the readers from outside the given circle have at least a minimum of competence with regard to the cultural codes of the country, its current and past political situation, history, language, and so on. The same context for texts from short-range cultures is only readable locally. In addition, this local readability becomes blurred when the condition for participation in the system of world literature is not only linguistic but also conceptual translatability. Therefore, it is definitely more profitable to orientate the texts towards what is globally readable than towards what is locally (and at the same time supranationally) important.

The argumentation presented here is not a complaint about the inevitable marginalisation of local cultures in world literature or in the global system of memory. However, it is a way of drawing attention to the fact that a false diagnosis of the relative balance within the designed, postulated system has very real effects for cultures that were marginalised within the previous systems (indeed much more hierarchical and geared towards creating global, eliminative narratives). The starting point for the design of truly open systems must be a more complete confrontation with reality, much less egalitarian than it seems at first glance. Only a full confrontation with a real closure of a global system can bring an idea for a real opening, even if it will not necessarily be an immediate or quick solution.

Translated by Kaja Szymańska

\section{Literature}

Apter E., Against World Literature: On the Politics of Untranslatability, London, New York 2013.

Assmann A., Cultural Memory and Western Civilization: Functions, Media, Archives, Cambridge 2011.

Assmann A., From Collective Violence to a Common Future: Four Models for Dealing with a Traumatic Past, in: Conflict, Memory Transfers and the Reshaping of Europe, eds. H. Gonçalves da Silva, A. Alves de Paula Martins, F. Viana Guarda, J.M. Sardica, Newcastle upon Tyne 2010, pp. 8-23.

Bloom H., The Western Canon: The Books and School of the Ages, London 1995.

Casanova P., The World Republic of Letters. Convergence: Inventories of the Present, transl. M.B. Devobise, Cambridge, MA, London 2004.

Czapliński P., Literatura światowa i jej figury, "Teksty Drugie” 2014, no. 4, pp. 13-40.

Czapliński P., Sploty, “Teksty Drugie” 2017, no. 1, pp. 9-17.

Damrosch D., How to Read World Literature, Malden, MA, Oxford 2009. 
Damrosch D., What Is World Literature?, Princeton, NJ, Oxford 2003.

Hayot E., On Literary Worlds, Oxford, New York 2012.

Kant I., Critique of Judgement, transl. J.C. Meredith, ed. N. Walker, Oxford 2007.

Kola A.F., Między komparatystyka literacka a literatura światowa, "Teksty Drugie" 2014, no. 4, pp. 41-63.

Kołodziejczyk D., Wojna światów? Postkolonialny kontrapunkt w nowej komparatystyce, "Teksty Drugie" 2014, no 4, pp. 64-84.

Moretti F., Conjectures on World Literature, "New Left Review" 2000, no 1, pp. 5468.

Nycz R., Kulturowa natura, staby profesjonalizm. Kilka uwag o przedmiocie poznania literackiego i statusie dyskursu literaturoznawczego, in: Kulturowa teoria literatury. Główne pojęcia i problemy, eds. M.P. Markowski, R. Nycz, Kraków 2006, pp. 5-38.

Nycz R., Nowa humanistyka w Polsce: kilka bardzo subiektywnych obserwacji, koniektur, refutacji, "Teksty Drugie" 2017, no. 1, pp. 18-40.

Olick J.K., The Politics of Regret: On Collective Memory and Historical Responsibility, New York 2007.

Rothberg M., Between Paris and Warsaw: Multidirectional Memory, Ethics, and Historical Responsibility, in: Memory and Theory in Eastern Europe, eds. U. Blacker, A. Etkind, J. Fedor, New York 2013, pp. 81-101.

Rothberg M., Multidirectional Memory: Remembering the Holocaust in the Age of Decolonization, Stanford, CA 2009.

Teaching World Literature, ed. D. Damrosch, New York 2009. 